\title{
3-D Modeling of a Polycrystalline Silicon Solar Cell Under Polychromatic Illumination: Effects of the Grain Size and the Recombination Velocity at the Boundaries
}

\author{
Mamadou Bamba Sene', Amadou Diao', Alioune Faye ${ }^{2}$, Cheikh Mbow ${ }^{2}$ \\ ${ }^{1}$ Solid State Physics and Materials Sciences Laboraty, Faculty of Sciences and Techniques, University of Cheikh Anta Diop, Dakar, Senegal \\ ${ }^{2}$ Fluid Mechanics and Applied Dynamics System Laboraty, Faculty of Sciences and Techniques, University of Cheikh Anta Diop, Dakar, \\ Senegal
}

\section{Email address:}

mbsene1@yahoo.fr (M. B. Sene)

\section{To cite this article:}

Mamadou Bamba Sene, Amadou Diao, Alioune Faye, Cheikh Mbow. 3-D Modeling of a Polycrystalline Silicon Solar Cell Under Polychromatic Illumination: Effects of the Grain Size and the Recombination Velocity at the Boundaries. American Journal of Modern Physics. Vol. 10, No. 3, 2021, pp. 55-59. doi: 10.11648/j.ajmp.20211003.13

Received: April 17, 2021; Accepted: May 18, 2021; Published: June 3, 2021

\begin{abstract}
In this paper, a three-dimensional study on a polycrystalline silicon solar cell under polychromatic illumination in an instational regime. The influence of grain size, recombination velocity at the grain boundaries on the density of the minority carriers of a silicon solar cell, is presented. Based on the continuity equation of the minority carriers in the solar cell base, the expressions of the photocurrent density and the photovoltage in function of the grain size, the recombination velocity, are deduced. The continuity equation of the carriers has been solved by a numerical method with boundary conditions and physical constants fixed in relation to our reference model. The influence of time $t$ on the density of the carriers and on the electric power was presented in this work also. The electrical voltage and current were studied according to the recombination velocity. The conversion efficiency according to the grain size and also presented an assessment of the performance of our model of study. The expressions of the output power and the energy conversion of the solar cell, are determined in order to optimize its functional state. We recall that, the objective is to make a numerical resolution, making fewer simplifying hypotheses so that the study is closer to reality compared to other methods of resolution.
\end{abstract}

Keywords: Solar Cell, Grain Size, Frequency, Photovoltage, Power, Photocurrent, Recombination Velocity

\section{Introduction}

More and more research on photovoltaic solar energy is intensifying and the yield, which was initially around $4 \%$, is now around $20 \%$ less. The performance is closely linked to the electronic and electrical properties of the solar cell [1]. There are other factors that can also affect the performance of the cell, such as the illumination and its frequency [1-2]. To optimize the performance of a photovoltaic cell, the characteristics of the recombination parameters must be well controlled and well characterized [2-3]. In logic of participation and contribute to research in this field, we have carried out a theoretical and numerical study in 3-D modeling of a silicon photopile.

\section{Theory}

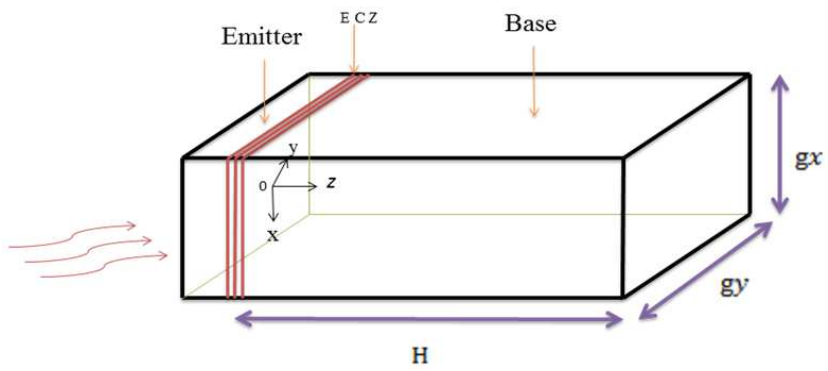

Figure 1. Grain structure of a polycrystalline silicon solar cell.

Where: $\mathrm{H}$ is the total base depth; gy and gx are respectively the grain sizes following $\mathrm{y}$ and $\mathrm{x}$ axes 
A grain size of a polycrystalline silicon solar cell under polychromatic illumination is presented in Figure 1 [1-4].

It is considered that the diffusion coefficient $\mathrm{D}$ is a constant. [4 - 7]

We considered a semiconductor that is ionized by incident radiation on the front panel. The ionizing radiation is absorbed and generates electron-hole pairs.

To model the transport of carriers we assume a low injection level in the absence of an applied field effects.

The three-dimensional off the continuity equation is written as: [2, 8 - 11]

$$
\begin{gathered}
\frac{\partial \delta(\mathrm{x}, \mathrm{y}, \mathrm{z}, \mathrm{t})}{\partial \mathrm{t}}-\mathrm{D}\left[\frac{\partial^{2} \delta(\mathrm{x}, \mathrm{y}, \mathrm{z}, \mathrm{t})}{\partial \mathrm{x}^{2}}+\frac{\partial^{2} \delta(\mathrm{x}, \mathrm{y}, \mathrm{z}, \mathrm{t})}{\partial \mathrm{y}^{2}}+\frac{\partial^{2} \delta(\mathrm{x}, \mathrm{y}, \mathrm{z}, \mathrm{t})}{\partial \mathrm{z}^{2}}\right]-\frac{\delta(\mathrm{x}, \mathrm{y}, \mathrm{z}, \mathrm{t})}{\tau}+ \\
\mathrm{G}(\mathrm{x}, \mathrm{y}, \mathrm{z}, \mathrm{t})=0
\end{gathered}
$$

with:

1) $\delta(x, y, z, t)$ the density of excess minority charge carriers in the base;

2) $G(x, y, z, t)$ the generation rate of the minority carriers;

3) D the diffusion coefficient;

4) $\tau$ the lifetime of the minority carriers

Considering that the generation rate depends on the variables $\mathrm{z}$ and $\mathrm{t}$, equation (1) becames:

$$
\begin{gathered}
\frac{\partial \delta(\mathrm{x}, \mathrm{y}, \mathrm{z}, \mathrm{t})}{\partial \mathrm{t}}-\mathrm{D}\left[\frac{\partial^{2} \delta(\mathrm{x}, \mathrm{y}, \mathrm{z}, \mathrm{t})}{\partial \mathrm{x}^{2}}+\frac{\partial^{2} \delta(\mathrm{x}, \mathrm{y}, \mathrm{z}, \mathrm{t})}{\partial \mathrm{y}^{2}}+\frac{\partial^{2} \delta(\mathrm{x}, \mathrm{y}, \mathrm{z}, \mathrm{t})}{\partial \mathrm{z}^{2}}\right]-\frac{\delta(\mathrm{x}, \mathrm{y}, \mathrm{z}, \mathrm{t})}{\tau}+ \\
\mathrm{G}(\mathrm{z}, \mathrm{t})=0
\end{gathered}
$$

Where the generation rate is given by: [1]

$$
G(z, t)=G_{0} \cdot G(z) \cdot e^{j \cdot \omega \cdot t}
$$

With

$\omega$ is the angular frequency modulation.

Hence, under these conditions, we have the equation that is written:

$$
\begin{gathered}
\frac{\partial \delta(\mathrm{x}, \mathrm{y}, \mathrm{z}, \mathrm{t})}{\partial \mathrm{t}}-\mathrm{D} \cdot\left[\frac{\partial^{2} \delta(\mathrm{x}, \mathrm{y}, \mathrm{z}, \mathrm{t})}{\partial \mathrm{x}^{2}}+\frac{\partial^{2} \delta(\mathrm{x}, \mathrm{y}, \mathrm{z}, \mathrm{t})}{\partial \mathrm{y}^{2}}+\frac{\partial^{2} \delta(\mathrm{x}, \mathrm{y}, \mathrm{z}, \mathrm{t})}{\partial \mathrm{z}^{2}}\right]-\frac{\delta(\mathrm{x}, \mathrm{y}, \mathrm{z}, \mathrm{t})}{\tau}+ \\
\mathrm{G}_{0}(1-\mathrm{R}) \cdot \mathrm{e}^{-\alpha \mathrm{x}} \cdot \mathcal{R} \mathrm{e}^{\mathrm{j} \cdot \mathrm{w} \cdot \mathrm{t}}=0
\end{gathered}
$$

To resolve equation (5), we need the following boundary conditions

1) at $\mathrm{t}=0$,

$$
\delta(0, \mathrm{y}, \mathrm{z}, 0)=\delta_{0}
$$

2) at the junction $(z=0)$ :

$$
\mathrm{D}\left[\frac{\partial \delta(\mathrm{x}, \mathrm{y}, \mathrm{z}, \mathrm{t})}{\partial \mathrm{x}}\right]_{\mathrm{z}=0}=\mathrm{S}_{\mathrm{f}} .\left.\delta(\mathrm{x}, \mathrm{y}, 0, \mathrm{t})\right|_{\mathrm{z}=0}
$$

3) at the back side $(z=H)$ :

$$
\begin{array}{r}
\mathrm{D}\left[\frac{\partial \delta(\mathrm{x}, \mathrm{y}, \mathrm{z}, \mathrm{t})}{\partial \mathrm{x}}\right]_{\mathrm{z}=\mathrm{H}}=-\left.\mathrm{S}_{\mathrm{b}} \cdot \delta(\mathrm{x}, \mathrm{y}, \mathrm{H}, \mathrm{t})\right|_{\mathrm{z}=\mathrm{H}} \\
\mathrm{D}\left[\frac{\partial \delta(\mathrm{x}, \mathrm{y}, \mathrm{z}, \mathrm{t})}{\partial \mathrm{y}}\right]_{\mathrm{y}= \pm \frac{\mathrm{gy}}{2}}= \pm \mathrm{S}_{\mathrm{g}} \mathrm{b} \cdot \delta\left(\mathrm{x}, \pm \frac{\mathrm{gy}}{2}, \mathrm{z}, \mathrm{t}\right) \\
\mathrm{D}\left[\frac{\partial \delta(\mathrm{x}, \mathrm{y}, \mathrm{z}, \mathrm{t})}{\partial \mathrm{x}}\right]_{\mathrm{z}= \pm \frac{\mathrm{gz}}{2}}= \pm \mathrm{S}_{\mathrm{g}} \mathrm{b} \cdot \delta\left(\mathrm{x}, \mathrm{y}, \pm \frac{\mathrm{gz}}{2}, \mathrm{t}\right)
\end{array}
$$

1) $S_{f}$ and $S_{b}$ the recombination are respectively the junction and rear side velocities of the minority carriers;

2) $H$ the thickness of the base. [1-4]

and

1) $S_{g} b$ the recombination velocity at the grain boundaries;

2) gy and gz are respectively the grain side following the $y$ and $\mathrm{z}$ axis.

Taking these approximations into account and after calculation, the transport equation of the charge carriers is reduced to the following algebraic system. This equation is a trigonal system that can only be solved by an iterative method. [12]

The density of the current photo due to the diffusion of minority charge carriers at the junction is given by Fick's law at the junction of the photopile:

$$
J=2 \cdot \mathrm{q} \cdot \mathrm{D}\left[\frac{\partial \delta(\mathrm{x}, \mathrm{y}, \mathrm{z}, \mathrm{t})}{\partial \mathrm{z}}\right] \mathrm{z}=0
$$

With q: the electron charge and D the diffusion coefficient of the minority carriers in the base.

The expression of the density of photos current at the junction is a function of the recombination velocity. [9]

There is, also, a photovoltage appearance which expression is given by Boltzmann's relationship: is

$$
\mathrm{V}=\mathrm{V}_{\mathrm{T}} \cdot \ln \left[1+\frac{\mathrm{Nb}}{\mathrm{n}_{0}^{2}} \cdot \delta(0)\right]_{\mathrm{z}=0}[9]
$$

Where

$\mathrm{Nb}$, is the base doping rate with acceptor atoms; $\mathrm{n}_{0}$, is the intrinsic density of minority shareholders; $V_{T}$ is the thermal voltage

The thermal voltage is defined by the following relationship

$$
\mathrm{V}_{\mathrm{T}}=\frac{\mathrm{KxT}}{\mathrm{q}}
$$

Where $\mathrm{K}$ is the Boltzmann constant, $\mathrm{T}$ is the absolute temperature at thermal equilibrium $\left(\mathrm{T}=300^{\circ} \mathrm{K}\right)$.

Considering the photo current density and the photovoltge expressions, we deduce the deduce the output power of the solar cell.

Power is an essential electrical parameter to characterize a photopile. It indicates the ability of the photopile to supply electricity to the external load connected to its terminals, it is all the greater as the photopile is of better quality.

The electrical power as called output power, is expressed.

As supplied by the photopile for polychromatic illumination is expressed as follows:

$$
\mathrm{P}=\mathrm{V} . \mathrm{J}
$$

Efficiency [8] is the ratio between the maximum electrical power supplied by the photopile and the power of the incident luminous flux received by this photopile.

The study of the power as a function of Sf shows that the powers for the maximum operating point are obtained for $\mathrm{Sf}$ $=10^{5} \mathrm{~cm} / \mathrm{s}$

Where 


$$
\begin{gathered}
\eta=\frac{P_{m}}{P_{\text {inc }}} \\
P_{\text {inc }}=100 \mathrm{~mW} / \mathrm{cm}^{2}
\end{gathered}
$$

\section{Results and Discussions}

\subsection{Density of the Minority Carriers in the Base}

The profile of the minority carrier's density according to the base depth, in presents in figure 2 :

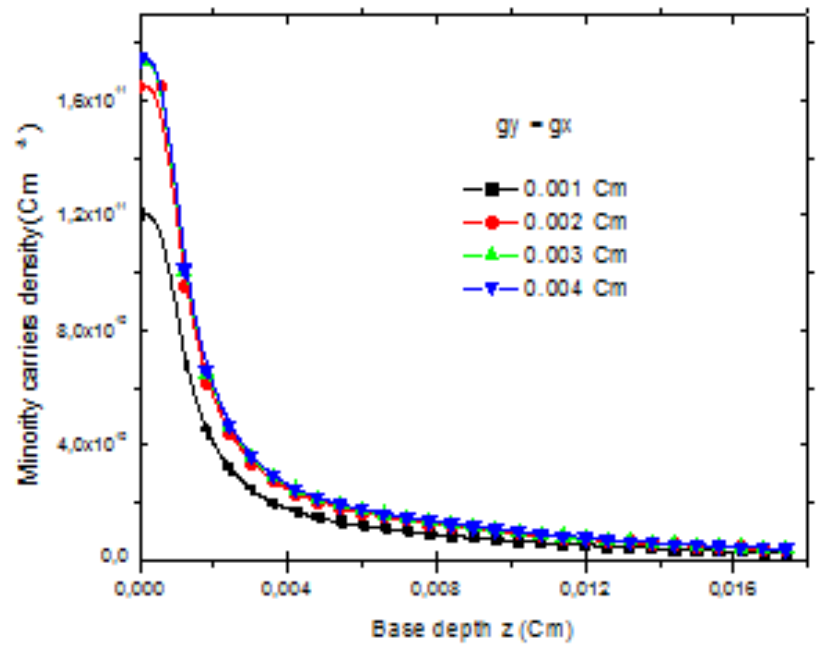

Figure 2. Minority carriers versus density base depth for different grain size values.

Figure 2: In figure 2, the minority carriers density decreases with the increase of the base depth. For a given grain size, at the vicinity of the junction, the minority carriers' density is much greater than the one obtained in the bulk of the solar cell since absorption of the incident photons is very important at the surface around the junction. We expect too in the bulk of the solar cell that there is recombination of the photogenerated minority carriers' or its grain boundaries, ar incease of the grain size, corresponds to an increase of the minority carrier's density amplitude. There, increasing the grain size leads to minimize the minority carrier's recombination centers at the grain boundaries. We note that the mean lifetime of the photogenerated carriers depends on the grain size [1314]. This predicts the expansion of the space load area when the grain size increases. [14].

In figure 3, we represent the profile of the minority carrier's density according to the base depth with different values of time $\mathrm{t}$ :

Figure 3 shows us that when the recombination rate increases the density of load carriers in the base decreases. In other words, we will say that the smaller the recombinations of the bearers, the higher the performance of a photopile. The trend today in photopile development is to realize photopiles with progressively lower surface recombination speeds to increase yields. [14-16]

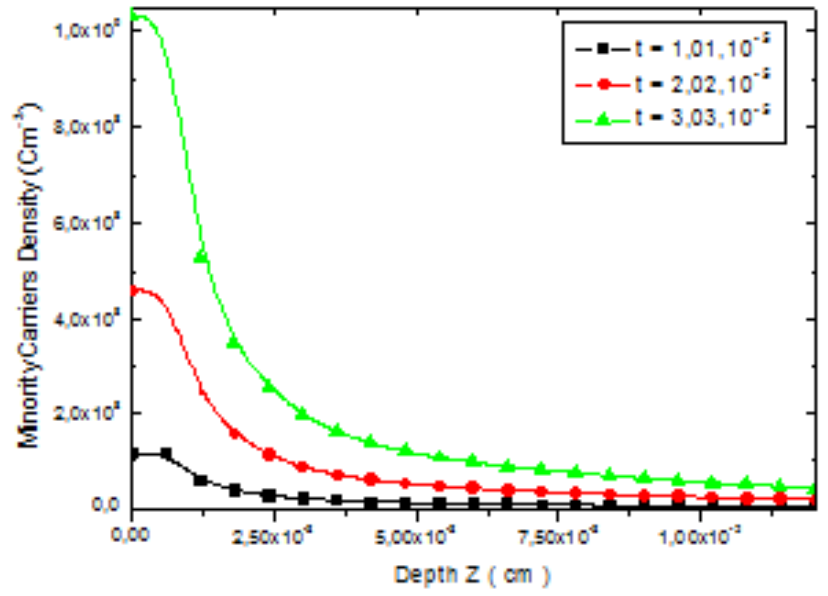

Figure 3. Minority carriers' density versus base depth for different values of time t.

\subsection{Photocurrent Density}

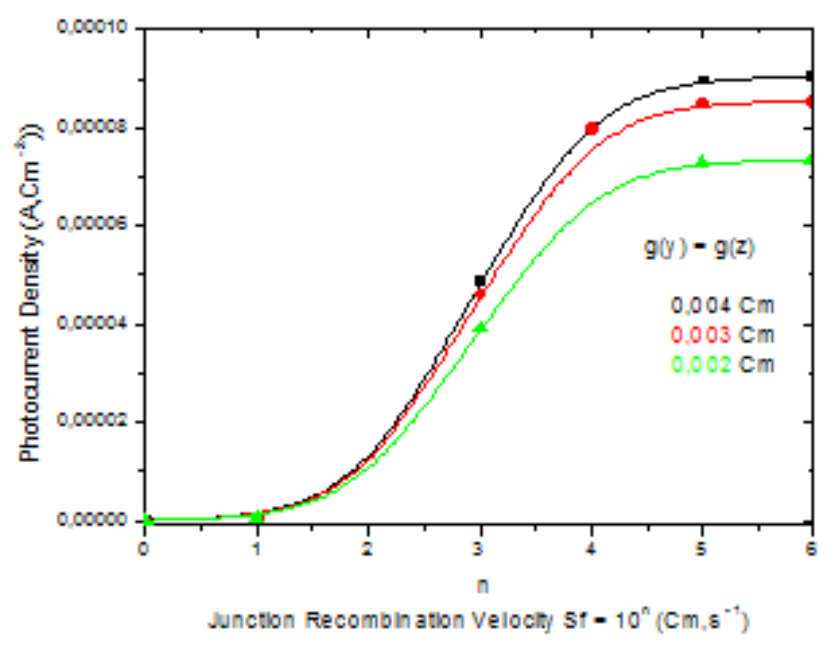

Figure 4. Change in photocurrent density based on recombination speed for different grain size values.

For a given grain size, the photocurrent density increases with the increase of the junction recombination velocity. We note two plateaus where the photocurrent density can be either small or high. The small values of the photocurrent, in the interval $\left[0 \mathrm{~m} . \mathrm{s}^{-1} ; 10 \mathrm{~m} . \mathrm{s}^{-1}\right]$ of the junction recombination velocity, correspond to the open circuit functioning of the solar cell: photogenerated minority carriers have not enough energy to cross the junction edge where they are stocked. In the interval $\left[10^{5}\right.$ m. $\mathrm{s}^{-1} ; 10^{6} \mathrm{~m} . \mathrm{s}^{-1}$ ] of the junction recombination velocity, the high values of the photocurrent correspond to the short circuit functioning of the solar cell: the photogenerated minority carriers have now enough energy to cross the junction in order to give the short circuit photocurrent.

The increase of the grain size lead to an increase of the photocurrent amplitude since there is a decrease of the recombination centers at the grains boundaries. [14]. 


\subsection{Photovoltage}

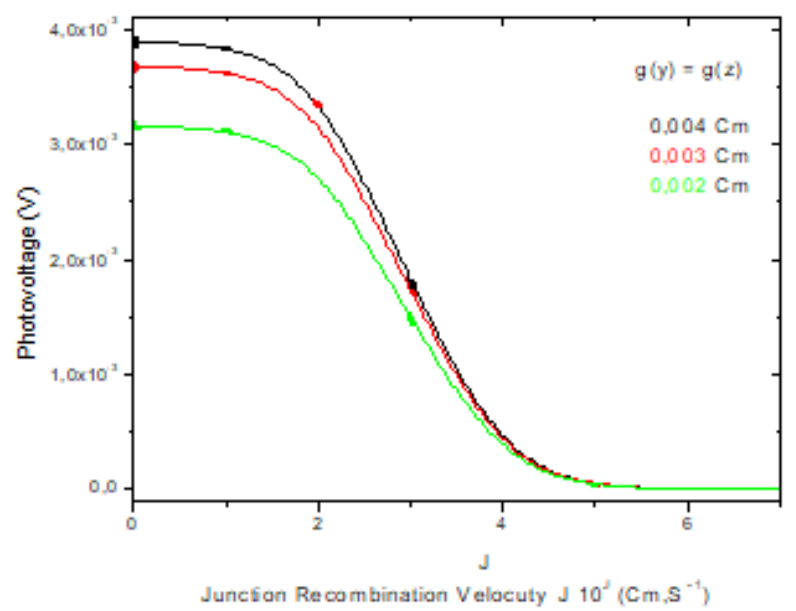

Figure 5. Variation in phototension density based on recombination speed for different grain size values.

In Figure 5, the photovoltage decreases with the increase of the junction recombination velocity. In open circuit functioning of solar cell, the stocked photo generated minority carriers around the junction edge, create a high photovoltage. But, in short circuit functioning of the solar cell, the photovoltage tends to zero since all of the photo generated minority carriers have crossed the junction. [18]

When we increase the grain size, there is also an increase of the photovoltage amplitude because of the recombination centers decrease.

\subsection{Electrical Power}

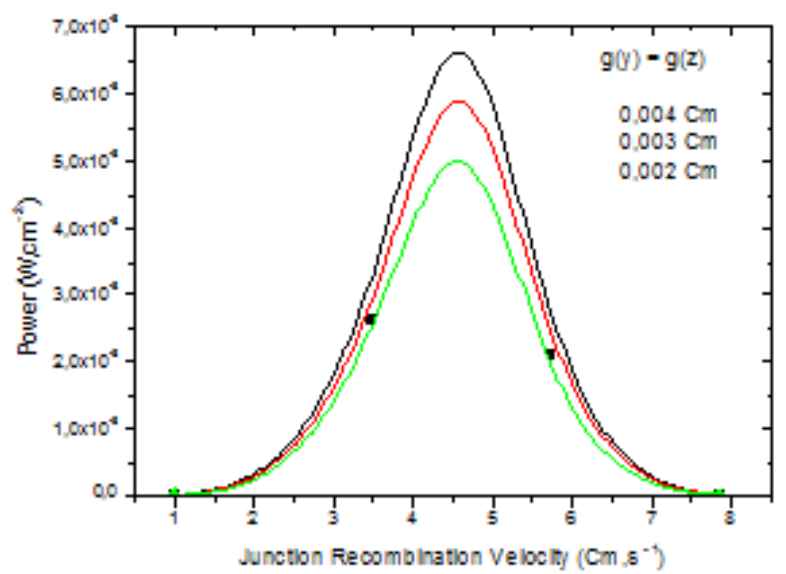

Figure 6. Variation in electrical power depending on recombination speed for different grain size values.

The three curves of the output power, in figure 6, present the same behavior. For a given grain size, the output power increases with the junction recombination velocity to wards a maximum value that corresponds to the maximum power and an optimum junction recombination velocity. Beyond the maximum power and the optimum junction recombination velocity, the output power de creases with the increase of the junction recombination velocity. [17]

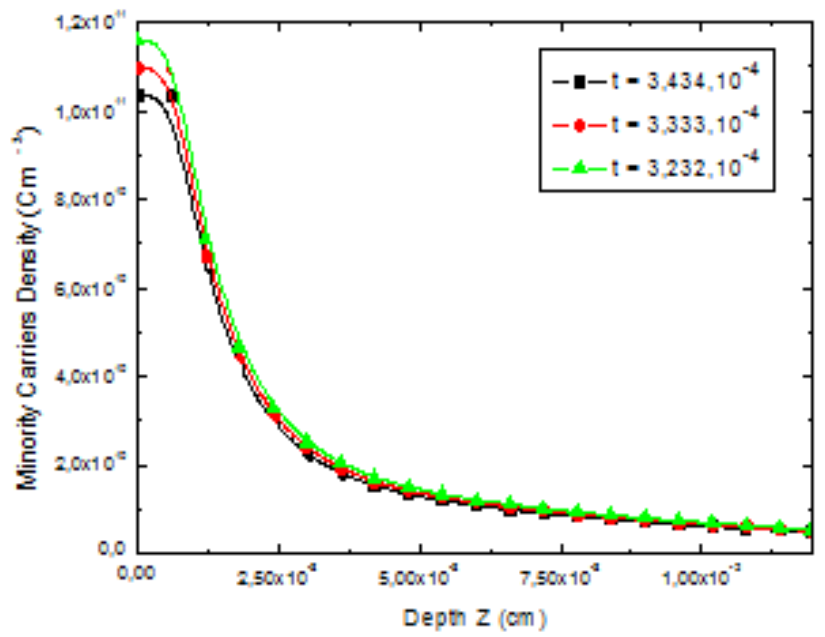

Figure 7. Density of load carriers according to basedepth for different values of time $t$.

Figures 4, 5 and 6 show how carrier density changes with time and when $t$ is less than $3.434 \mathrm{E}-4$ the permanent regime is not reached. It is concluded that for low times the study can becarried out on a permanent bass and for shortperiods working on a permanent basis is veryidealistic.

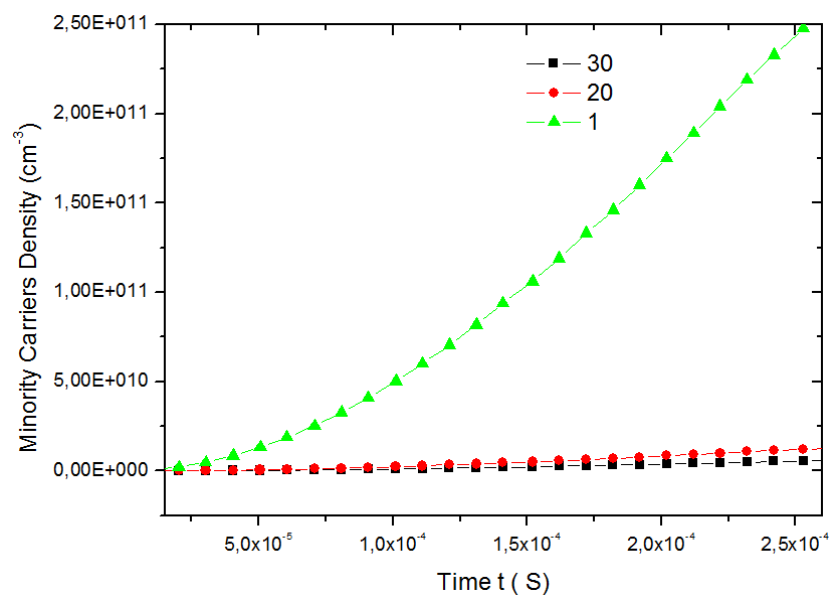

Figure 8. Minority carriers' density according to time t for different position.

Shows that for a position close to the light-illuminated face, load carrier density varies exponentially with time t. When you move away from this face, the time-to-time variation decreases very quickly to become negligible.

Representation of load-bearing density over time $t$ shows that a time-t study takes more account of all phenomena when one is close to the illuminated face, as when one move away from the illuminated face, the impact of time and thus decreases the approximation of conducting such as any approximation.

Table 1. Energy Conversion of the solar cell.

\begin{tabular}{llll}
\hline gy and gz & $\mathbf{0 , 0 0 2}$ & $\mathbf{0 , 0 0 3}$ & $\mathbf{0 , 0 0 4}$ \\
\hline $\mathrm{P}_{m}\left(\mathrm{~W} / \mathrm{cm}^{2}\right)$ & $6,63.10^{-08}$ & $7,79.10^{-08}$ & $8,76.10^{-08}$ \\
$\mathrm{y}(\%)$ & 6,63 & 7,79 & 8,76 \\
\hline
\end{tabular}


The increase of the grain size corresponds to an increase of the maximum output power provided by the solar cell since there is a link between the maximum output power and the energy conversion, we note an increase of this energy conversion with grain size increasing. [18].

\section{Conclusion}

A theoretical study of a polycrystalline silicon solar cell have been done. Taking into account of the grain size, the junction recombination velocity and the recombination velocity at the grain boundaries, expressions of the minority carriers density, the photocurrent, the photovoltage and the power, were deduced. The increase of the recombination velocity at the grain boundaries, diminishes drastically the power and the energy conversion however we note an enhancement of these quantities with the grain size. If we generalize, we can say that the study we have just presented has allowed us for determining the electrical parameters of a solar cell.

\section{References}

[1] M. M. Deme, S. Mbodji, S. Ndoye, A. Thiam, A. Dieng and G. Sissoko Influence of illumination incidence angle, grain sizeand grain boundary recombination velocity on thefacial solar cell diffusion capacitance. Renewable Energy Review Vol. $13 \mathrm{~N}^{\circ} 1$ (2010) $109-532$.

[2] M. Zoungrana, I. Zerbo, F. I. Barro, R. Sam, F. Touré, M. L. Samb and F. Zougmoré $3-\mathrm{D}$ Modeling of the influence of grain size and Recombination velocity at grain joints a Polycrystalline Silicon Solar Cell under clear concentration. Renewable Energy Review Vol. 14 N4 (2011) 649 - 664.

[3] I. Zerbo, M. Zoungrama, A. D. Seré, F. Ouedraogo, R. Sam, B. Zouma, et Zougmoré, Influence of an Electromagnetic wave on Silicon Solar Cell under Multispectral Illumination in Static Mode. Renewable Energy Review Vol. 14 N’3 (2011) $517-532$.

[4] Meimouna MINT SIDI DEDE, Mor Ndiaye, Sega GUEYE, Mamadou Lamine BA, Ibrahima DIATTA, Marcel Sitor DIOUF, El Hadj SOW, Amadou MamourBA, Massamba DIOP, and Gregoire SISSOKOO ptimum base thickness determination technique asapplied to $\mathrm{n} / \mathrm{p} / \mathrm{p}+$ silicon solar cell under short wavelengths monochromatic illumination International Journal of Innovation and Applied Studies ISSN 2028-9324 Vol. 29 No. 3 Jun. 2020, pp. 576-586.

[5] Matar Gueye, Hawa Ly Diallo, Attoumane Kosso Mamadou Moustapha2, Youssou Traore1, IbrahimaDiatta1, Gregoire Sissoko1Ac Recombination Velocity in a Lamella Silicon SolarCell World Journal of Condensed Matter Physics, 2018, 8, 185-196.

[6] Ousmane Diasse, Amadou Diao, Mamadou Wade, Marcel Sitor Diouf, Ibrahima Diatta, Richard Mane, Youssou Traore, Gregoire Sissoko Back Surface Recombination Velocity Modeling in White Biased Silicon Solar Cell under Steady StateJournal of Modern Physics, 2018, 9, 189-201.
[7] Amadou Diao, Mamadou Wade, Moustapha Thiame, Grégoire Sissoko Bifacial Silicon Solar Cell Steady Photo conductivity under Constant Magnetic Field and Junction Recombination Velocity Effects Journal of Modern Physics, 2017, 8, 22002208.

[8] Senghane Mbodji, Martial Zoungrana, Issa Zerbo, Biram, Gregoire Sissoko Modelling Study of Magnetic Field's Effects on Solar Cell's Transient Decay World Journal of Condensed Matter Physics, 2015, 5, 284-293.

[9] E. F Nogotov, Applications of Numerical Heat Transfer, Ed. McGraw Hill book company, New York (1978).

[10] H. El Ghitani and S. Martinuzzi, Influence of dislocations on electrical properties of large grained polycrystalline silicon cells. II. Experimental results Journal of Applied Physics 66, 1989, pp-1723-1726.

[11] N. Thiam, A. Diao, M. Wade, M. Ndiaye, I. Zerbo, M. Sarr, A. S. Maîga and G. Sissoko Study of the Photo thermal Response of a Monofacial Solar Cell in Dynamic Regime Under a Multispectral Illumination. Research Journal of Applied Sciences, Engineering and Technology 5 (1): 134-141, 2013.

[12] F. Poupaud, On a System of Nonlinear Boltmann Equations of Semiconductor Physics, SIAM Journal on Applied Mathematics 50 (6). Décembre 1990 Vol. 50:, Issue, 6 Pages. 1593-1606.

[13] Nzonzolo, Désiré Lilonga, Camille Nziengui Mabika, Grégoire Sissoko Two - Dimensional Finite Element Method Analysis Effect of the Recombination Velocity at the Grain Boundaries onthe Characteristics of a Polycrystalline Silicon Solar Cell. Circuit and Systems, 2016, 7, 4186-4200.

[14] I. Ly, O. H. Lemrabott, B. Dieng, I. Gaye, S. Gueye, M. S. Diouf and G. Sissoko. Technique for Determining the Recombination Parameters and the Range of their Validity of a Polycrystalline Silicon bifacial Solar Cell under Constant Multispectral Illumination in Static Mode Renewable Energy Review Vol. 15 N²( 2012) 187 - 206.

[15] Amal Nadril, Yves Duternail-Couvat, Thierry Duffar. Twodimensional numerical modeling of grainstructure in multicrystalline silicon ingot. Journal ofcrystal growth 385, 16-21, 2014.

[16] Alfred DIENG, Ndeye THIAM, Mamadou LamineSAMB, Amadou Seîdou MAIGA, Fabé IdrissaBARRO, Grégoire Sissoko 3 - D study of a polycrystalline silicon solar cell: Influence of grain size and recombination velocity at grain joints on Electrical Parameters. Journal of Sciense. Vol. 9, $\mathrm{N}^{\circ} 1$ (2009) 51-63.

[17] E. H. Ndiaye, G. Sahin, M. Dieng, A. Thiam, H. L. Diallo, M. Ndiaye, and G. Sissoko, "Study of the Intrinsic Recombination Velocity at the Junction ofSilicon Solar under Frequency Modulation and Irradiation," Journal of Applied Mathematics and Physics, vol. 3, pp. 1522-1535, November 2015.

[18] G. Sahin, M. Dieng, M. A. O. E. Moujtaba, M. I. Ngom, A. Thiam, and G. Sissoko, "Capacitance of Vertical Parallel Junction Silicon Solar Cell under Monochromatic Modulated Illumination," Journal of Applied Mathematics and Physics, vol. 3, pp. 1536-1543, 2015. 